\title{
Hydroponic wheat production using fresh water and treated wastewater under the semi-arid region
}

\author{
Fatima Hasan Abdulla Ahmed Al Hamedi', Kandhan Karthishwaran ${ }^{1,2}$, \\ Mohammed Abdul Mohsen Alyafei ${ }^{1 *}$ \\ ${ }^{1}$ Department of Integrative Agriculture, College of Food and Agriculture, PO Box No. 15551, United Arab Emirates University, Al Ain, UAE, \\ ${ }^{2}$ College of Medicine and Health Sciences, PO Box No. 17666, United Arab Emirates University, Al Ain, UAE
}

\section{A B S TR A C T}

\begin{abstract}
The use of alternative water sources such as tertiary treated wastewater is considered very important for growing crops due to irrigation water scarcity, particularly in arid regions like the UAE. Treated wastewater contains nutrients that are essential for the cultivation of nutritively important crops. In the present study, we evaluated and compared the effect of differently treated wastewater samples using an auto-pot watering hydroponic system. The growth solution was prepared using well water $(\mathrm{H})$, and treated wastewaters collected from different geological areas Abu Dhabi $(\mathrm{H} 1)$ and Al Ain (H2). The study was carried out with two wheat varieties (ESWYT and SAWYT)) obtained from the CIMMYT Genetic Resource Centre. Temperature, $\mathrm{pH}$, and electrical conductivity (EC) of the growth solutions were monitored. Twelve weeks after planting, the wheat plants were harvested and root, shoot and spike biomasses were measured. The $\mathrm{H} 2$ treatment had a positive impact on wheat growth and different morphological characters, especially for SAWYT variety. Moreover, for both the varieties, highest grain yield, total chlorophyll and carotenoids were observed with $\mathrm{H} 2$ treatment. Between the treatments $\mathrm{H} 1$ and $\mathrm{H} 2$, there was only a slight variation in protein content and fiber content for both the wheat varieties. The growth of wheat plants was inhibited by $\mathrm{H} 1$ treatment due to the high electrical conductivity of the wastewater. The final kernel was analyzed and the levels of Ca, $\mathrm{K}$ and $\mathrm{P}$ were higher in plants grown in $\mathrm{H} 2$. The study revealed appreciable results suggesting that the hydroponic effluents are a strong fertilizer source. In addition, the use of treated wastewater in the irrigation of wheat crops in hydroponic systems has been considered as a useful alternative wastewater disposal method without the possibility of accumulation of heavy metals in the soil.
\end{abstract}

Keywords: Hydroponic system; Wastewater; Food production; Wheat; Heavy metal

\section{INTRODUCTION}

There is a growing need for food production due to population and unpredictable climatic changes in the world. In order to balance the demand, it is assumed that about $33 \%$ of earth's land surface will be utilized as cropland (Zhang et al., 2019). The United Arab Emirates (UAE) is one of the countries facing high water scarcity. Around four-fifth of the land of the UAE has been surveyed as hyper-arid desert land with the level of annual rainfall being less than 120 millimeter. Also, the rainfall pattern is unbalanced with respect to regularity and quantity year after year (Al-Muaini et al., 2019).Thus the utilization of wastewater in agriculture is the need of the hour due to water crisis. However, increased population and urbanization produce more wastewater (Koop and van Leeuwen, 2017). Re-utilization of wastewater does not only provide a better alternative for the regions facing water scarcity, but also helps in saving freshwater for drinking and other consumption purposes.

Wastewater produced in the UAE makes $5 \%$ of the total water resources, which may get increased to $15 \%$ in the upcoming decades. Owing to urbanization, use of domestic wastewater for irrigation purposes is on the rise in the UAE (Murad et al., 2007). The treated wastewaters in arid countries usually contain mild salinity with considerable amount of toxic heavy metals. As a result, they can pollute soil, affect crop productivity, induce toxicity and lead to health issues (Nouri et al., 2017). To avoid these complications, wastewater usage has been implemented in forestry and forage irrigations. Hence, much care is needed in water management system to improvise the harmless use of wastewater in agriculture. The features of the waste

\footnotetext{
*Corresponding author:

Dr. Mohammed Abdul Mohsen Alyafei, Department of Integrative Agriculture, College of Food and Agriculture, PO Box No. 15551,

United Arab Emirates University, Al Ain, United Arab Emirates. Fax No.: +971-3-7134343. E-mail: mohammed.s@uaeu.ac.ae
} 
water relies majorly on the kind of sewer compilation system (separate or combined), the entry of industrial waste into the sewer, type of wastewater treatment technique, the purity of domestic fresh water and population over the area (Kamel and Nada, 2008).

Different types of waste water treatment have been developed, which include stabilization ponds, activated sludge, trickling filter or any combination of these techniques. Apart from the existing treatment plants, few more plants are going to be constructed before 2020 by the UAE government (Aleisa et al., 2017). However, the municipal wastewater contains various inorganic substances carried through the domestic, hospital and industrial wastes. As such wastes are usually loaded with cadmium, arsenic, chromium and lead, the well-known toxic heavy metals; pathogenic microbes are sparsely present in the raw wastewater (Yadanaparthi et al., 2009). Certainly, levels of pathogenic bacteria are comparatively less in wastewater than viruses and helminthes group of species. The presence of decomposition products of toxic herbicides and pesticides can also be challengeable in wastewater treatment (Kabra et al., 2012).

Though technology and modernization have brought up the alternatives to reuse wastewater, the nutrient availability in the treated wastewater is less when compared to the fresh water. In this regard, hydroponics would be a better choice to avoid the hazards of re-using the wastewater for agriculture in the arid and semi-arid regions as the technique provides soil less and harmless platform (Al-Karaki, 2011). Also, this type of cultivating system would be a practical idea of tackling global issues like water crisis, environmental pollution and imbalanced eco-system. Hydroponic system mainly uses treated wastewater and it has also been studied that some of the plants are capable bearing the risks of wastewater (Vaillant et al., 2004).

The use of wastewater in agriculture tends to accumulate the trace amounts of harmful elements and heavy metals in the soil. The prolonged accumulation of such elements could end up with poor ground water quality (Rababah and Al-Shuha, 2009). Countries like the UAE, hit by water crisis, need water treatment and agriculture management systems that ensure precise water consumption to produce green fodder with high yield. To fight the problems of water crisis and poor yield, hydroponic technique is regarded. Bradley and Marulanda (2000) have reported that water needed in hydroponics for production of green fodder is only about 10-20\% of water needed in soil culture to generate equal crop yield. Karaki and Hashimi (2011) have studied that fodder can be grown within 8 days by hydroponic system. Among the crops of barley, cowpea, alfalfa, sorghum they have grown, barley and cowpea have been found to be the best crops, whose yield were about $654 \mathrm{Kg} / \mathrm{m}^{3}$ of water. Based on the above facts, the current research focuses on the investigation of growth of wheat by hydroponics with well water and different treated wastewaters and the factors affecting it.

\section{MATERIAL AND METHODS}

\section{The site and experimental setup}

The experiment has been done in an outdoor hydroponic pot-culture designing method under natural solar radiation and temperature conditions at $\mathrm{Al} \mathrm{Foah} \mathrm{farm} \mathrm{in} \mathrm{Faculty} \mathrm{of}$ Food and Agriculture, UAE University between December 2018 to April 2019. The system manufactured in the UK was purchased from the local market. It is designed with Autopot and AQUAvalve watering technology to control water flow. The roots of the plantlets were completely dipped in the nutrient solution (Fig. 1). Perlite was used as the growing medium.

\section{Crop and management}

Two different genotypic advanced lines derived from the international trial $33^{\text {rd }}$ ESWYT (V1) and $20^{\text {th }}$ SAWYT (V2) were used as targets for this research and these wheat varieties were obtained from the CIMMYT Genetic Resource Centre, El Batan, Mexico.

\section{Irrigation and plantation}

Two different treated wastewater (TWW) from Al Wathba, Abu Dhabi and Al SAAD, Al Ain were used for experimental water. Normal local well water was used as control. The irrigated plant was grown in a hydroponic system. The experimental plan used was factorial based and completely randomized. Wheat seeds were germinated for 10 days, and then 13 seedlings were transplanted in each pot. The temperature was maintained at $38.4^{\circ} \mathrm{C}$ with a $12 \mathrm{~h}$ light and $12 \mathrm{~h}$ dark lighting schedule. The growth solution was prepared using the method described by Hoagland and Arnon (1950). The physical and chemical parameters of the three different kinds of growth solutions were analyzed following the standard methods. Temperature, $\mathrm{pH}$, and EC of the different kinds of water were monitored using combined portable $\mathrm{pH} / \mathrm{EC} / \mathrm{TDS} /$ Temperature meter (Hanna instrument, USA).

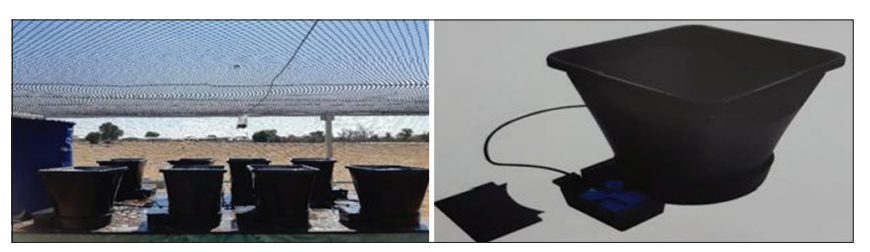

Fig 1. Hydrophonic system for the cultivation of wheat plant. 


\section{Analysis of agronomical parameters}

After 12 weeks of planting, wheat plant samples were harvested to evaluate the agronomical parameters such us plant length, root length, plant weight, dry weight, flag length and area, number of heads and head length.

\section{Estimation of chlorophyll and carotene}

The chlorophyll (both a and b) and carotene contents have been analyzed by the method described by Porra et al., (1989) with slight modifications. Briefly, $1 \mathrm{~g}$ of freshly picked leaf sample was homogenized in a pestlemortar with $5 \mathrm{ml}$ of distilled water. The ground paste was transferred to a $15 \mathrm{ml}$ centrifuge tube and made up to $10 \mathrm{ml}$ using distilled water. Then, $0.5 \mathrm{ml}$ of the supernatant was transferred to a tube containing $4.5 \mathrm{ml}$ of $80 \%$ acetone. After that, the homogenized contents were centrifuged at $4000 \mathrm{rpm}$ for $15 \mathrm{~min}$ at $4^{\circ} \mathrm{C}$ and subjected to colorimetry. From the absorbance (A) value of the supernatant, the total chlorophyll, chlorophyll-a, chlorophyll-b and carotenoid contents were estimated using the following equations:

$$
\begin{gathered}
\text { Total Chlorophyll: 20.2(A645) + 8.02(A663) } \\
\text { Chlorophyll a: } 12.7(\mathrm{~A} 663)-2.69(\mathrm{~A} 645) \\
\text { Chlorophyll b: } 22.9(\mathrm{~A} 645)-4.68(\mathrm{~A} 663) \\
\text { Carotenoid: }[\mathrm{A} 480+(0.114(\mathrm{~A} 663)-(0.638- \\
\text { A645)] } \times \mathrm{V} / 1000 \times \mathrm{W}
\end{gathered}
$$

\section{Estimation of fiber and crude protein content}

Grain samples were randomly selected and their protein and fiber contents were analyzed following the Commission Regulation (EU) No 691/2013 of 19 July 2013 amending Regulation (EC) No 152/2009. The crude fiber was determined as the residue after sequential treatment with hot $\mathrm{H}_{2} \mathrm{SO}_{4}$ (conc. $1.25 \%$ ) and hot $\mathrm{NaOH}(1.25 \%$ ) according to Weende method by Fibertec 2023 FiberCap system (Foss Tecator AB, Sweden). The fiber component analyses of the samples were done on an ANKOM 220 Fiber Analyzer (ANKOM Technology, USA). Acid detergent fiber (ADF), neutral detergent fiber (NDF) and acid detergent lignin (ADL) were analyzed using cell wall detergent fractionation method (Faithfull, 2002). Crude protein content was determined by the Kjeldahl method (Magomya et al., 2014).

\section{Elemental analysis}

The N, P, and K contents in root, shoot and spike of both the wheat varieties were analyzed before and after cultivation using ICP-OES (P and K) and Kjeldahl method $(\mathrm{N})$. Microelements, secure elements, and trace element contents were determined following the methodology reported by Bressy et al. (2013). Similarly, the method proposed by Ravichandran et al. (1995) was followed for the calculation of enrichment factor. The accumulation of heavy metals in the plant parts was determined by the standard method of NFISO 11466 (AFNOR, 1995) using UNICAM atomic absorption spectrophotometer (AAS).

\section{Data analysis}

The data were statistically analyzed using mean and standard deviations. Analysis of variance among the treatments was conducted using $t$-test and 'p' values were taken as an indicator of significant differences among the treatments.

\section{RESULTS AND DISCUSSION}

Due to the industrial revolution and increasing population, the contaminated and wastewater disposal is a major issue. The council of scientific and industrial Research (CSIR) has instructed to reuse the wastewater for cultivation (Aulakh et al., 2009). Physiochemical features such us pH, temperature, EC and chemical parameters such as dissolved oxygen (DO), trace and heavy metals content of the treated water play a crucial role in plant growth and physiological development in hydroponic system.

Based on this scientific and social impact, the physiochemical features of the urban wastewater (Abu Dhabi and Al Ain) were studied. Interestingly, there was a significant difference $(p=0.05)$ among all the physiochemical parameters of all the three wastewater samples. The $\mathrm{pH}$ range was 6.537.70, 6.80-7.86 and 7.00-7.98 for well water (control), H1 and $\mathrm{H} 2$ respectively. The EC of the well water (control), $\mathrm{H} 1$ and $\mathrm{H} 2$ ranged from $0.30-1.76,6.60-8.49$ and 1.17$2.61 \mathrm{mS} / \mathrm{cm}$ respectively. The temperature fluctuated as the environmental condition changed. It was between $16.0^{\circ} \mathrm{C}$ and $30.3^{\circ} \mathrm{C}$. The growth solution was renewed every seven days or when the level of the solution in the reservoir was low. The overall physiochemical findings revealed that the $\mathrm{H} 1$ had a high concentration of sodium due to the location of the city (near the coastal area).

Based on the above analysis, growth solutions were prepared from the treated wastewaters (Table 1). The overall quality of $\mathrm{H} 2$ was better than $\mathrm{H} 1$. Calcium (Ca), magnesium $(\mathrm{Mg})$, sodium $(\mathrm{Na})$, potassium $(\mathrm{K})$, and chloride $(\mathrm{Cl})$ were present in higher concentrations in both wastewater samples compared to the well water. Similarly, lesser amounts of iron (Fe), selenium (Se), nickel (Ni) and strontium (Sr) were recorded in the wastewater samples compared to the control. The concentrations of these trace elements and heavy metals are considered lower than those recommended for nutrient solutions in crop production (e.g., vegetables) under hydroponic systems (Pais and Jones, 1997). 
Table 1: Physico- chemical characteristics of irrigated wastewater samples collected from Abu Dhabi and Al Ain

\begin{tabular}{|c|c|c|c|c|}
\hline \multicolumn{2}{|l|}{ Parameters } & Control & Abu Dhabi (H1) & Al Ain (H2) \\
\hline \multicolumn{2}{|l|}{$\mathrm{pH}$} & 7.55 & 7.00 & 7.15 \\
\hline \multicolumn{2}{|l|}{$\mathrm{EC}(\mathrm{dS} / \mathrm{m})$} & 1.37 & 7.98 & 1.88 \\
\hline \multicolumn{2}{|l|}{ TDS (ppm) } & 889.90 & 5582.50 & 1223.25 \\
\hline \multicolumn{2}{|l|}{ Total N (ppm) } & 61.45 & 56.95 & 41.25 \\
\hline \multicolumn{2}{|l|}{ SAR } & 0.71 & 9.95 & 3.39 \\
\hline \multirow[t]{4}{*}{ Cations (ppm) } & $\mathrm{Ca}$ & 95.96 & 202.73 & 84.92 \\
\hline & $\mathrm{Mg}$ & 29.34 & 131.20 & 31.93 \\
\hline & $\mathrm{Na}$ & 40.28 & 903.68 & 176.45 \\
\hline & $\mathrm{K}$ & 79.00 & 135.67 & 64.13 \\
\hline \multirow[t]{4}{*}{ Anions (ppm) } & $\mathrm{Cl}$ & 110.05 & 2137.00 & 292.90 \\
\hline & $\mathrm{CO} 3$ & 0.00 & 0.00 & 0.00 \\
\hline & $\mathrm{HCO} 3$ & 61.05 & 83.90 & 99.15 \\
\hline & SO4 & 111.70 & 326.25 & 229.31 \\
\hline \multirow{16}{*}{$\begin{array}{l}\text { Trace and } \\
\text { Heavy Metals } \\
\text { (ppm) }\end{array}$} & Al & 0.00 & 0.00 & 0.00 \\
\hline & As & 0.07 & 0.00 & 0.00 \\
\hline & B & 0.33 & 0.29 & 0.36 \\
\hline & $\mathrm{Ba}$ & 0.00 & 0.00 & 0.00 \\
\hline & $\mathrm{Cd}$ & 0.00 & 0.00 & 0.00 \\
\hline & Co & 0.00 & 0.00 & 0.00 \\
\hline & $\mathrm{Cr}$ & 0.00 & 0.00 & 0.00 \\
\hline & $\mathrm{Cu}$ & 0.04 & 0.02 & 0.02 \\
\hline & $\mathrm{Fe}$ & 1.88 & 1.85 & 1.05 \\
\hline & $\mathrm{Mn}$ & 0.12 & 0.00 & 0.01 \\
\hline & Mo & 0.02 & 0.02 & 0.04 \\
\hline & $\mathrm{Ni}$ & 0.04 & 0.04 & 0.03 \\
\hline & $\mathrm{Pb}$ & 0.04 & 0.01 & 0.01 \\
\hline & Se & 0.25 & 0.62 & 0.42 \\
\hline & $\mathrm{Sr}$ & 0.00 & 0.30 & 0.07 \\
\hline & $\mathrm{Zn}$ & 0.11 & 0.09 & 0.06 \\
\hline
\end{tabular}

\section{Agronomical and morphological parameters}

After 12 weeks of plantation, the wheat plant samples were harvested to measure the agronomic parameters like number of head, root and spike weight and plant dry weight (Fig. 2). The findings of this experiment revealed that irrigation with $\mathrm{H} 2$ had a significant influence on the growth of the plant $(102.62 \mathrm{~cm})$ and root length $(14.80 \mathrm{~cm})$. There was an increase in growth rate, root length, flag leaf length $(18.39 \mathrm{~cm})$ and area $(13.51 \mathrm{~cm})$. Similarly the uppermost head length $(11.51 \mathrm{~cm})$ and $54.40 \%$ biomass were recorded, which indicate that the irrigation treatment with $\mathrm{H} 2$ generally enhances plant growth (Fig. 3). The findings of the agronomic parameters suggested that the growth of wheat varieties vary in the three different growth solutions. However, irrigation with $\mathrm{H} 2$ significantly improved the agronomic parameters compared to the other two growth solutions. This was furthers confirmed by the morphological parameters such us number of heads, height and weight of the different plant parts under two different irrigation treatments.

The assessment of the morphological parameters indicates that $\mathrm{H} 2$ treatment resulted in greater number of heads especially in wheat variety (V1). Moreover, the weight of the root, spike and plant weight reach the highest for the same experiment when compared to untreated control and H1 treatment (Fig. 4). Similar observation has also been made by Bhattarai et al. (2017), who documented a plant length of $89.83 \mathrm{~cm}$, spike length of $9.33 \mathrm{~cm}$, grain per spike $(43.66 \mathrm{~cm})$ and thousand kernel weight of $36.07 \mathrm{~g}$ using treated wastewater from $\mathrm{Al}$ Ain (H2). These agronomical and morphological findings are consistent with the study conducted by Abdelkhalek et al. (2016); Torrion and Stougaard (2017). The inferior morphological parameters and hindrance of plant growth with $\mathrm{H} 1$ treatment are due to the high salinity of this wastewater $(8.0 \mathrm{dS} / \mathrm{m})$. The high concentration of salinity can inhibit the wheat growth and yield. It leads to an imbalance of ion distribution and interrupts the photosynthesis (Sudhir and Murthy, 2004; Sharifi and Mohammadkhagni, 2016). These findings reveal that irrigation with wastewater sourced from $\mathrm{Al}$ Ain (H2) positively influences the growth of wheat plant. This shows the non-toxic nature of treated effluent. The desirable percentage of plant growth was achieved due to the cumulative effect of reduced concentration of total dissolved solids (TDS), EC, biochemical oxygen demand (BOD) and heavy metals in treated wastewater collected from $\mathrm{Al}$ Ain $(\mathrm{H} 2)$ compared to the treated wastewater sourced from Abu Dhabi (H1).

\section{Estimation of chlorophyll and carotene content}

The plant pigments chlorophyll and carotene are essential for photosynthetic process. In the present study, chlorophyll (A, B and Total) and carotenoid contents were measured in the leaves close to the flowering shoot of the wheat plants (Fig. 4). Total chlorophyll and carotene content were higher in plants chlorophyll and carotene content were higher in plants treated with $\mathrm{H} 2$, especially for wheat variety (V1) (Fig. 5). As the salinity was high in H1, it affected the function of the photosynthetic mechanism, particularly photosystem B, whereas in $\mathrm{H} 2$ (which has less salinity) a treated plant leaf, carotenoid content was higher. This is in accordance with previous studies (Rahneshan et al., 2018). Carotenoids can scavenge oxygen free radicals, and high levels of carotenoids in the cells indicate the relative tolerance to stress.

\section{Analysis of nitrogen (N), phosphorous (P) and potassium (K) content}

The irrigated wastewaters enriched with considerable amount of macro-inorganic elements are considered essential for enhancing plant growth and productivity. Among them, the role of sodium, potassium, and phosphorus is crucial for plant growth (Grusak et al., 2001). Elimination of any of these microelements may cause growth retardation, signs of deficiency or affect natural 


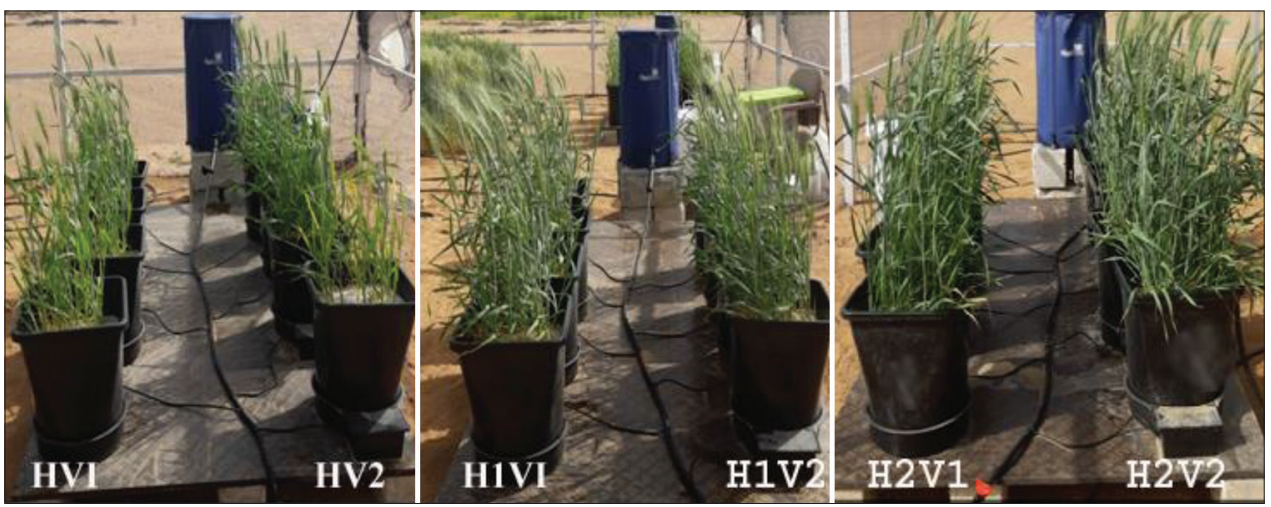

Fig 2. Different morphology parameters of wheat plant during the experimental period.

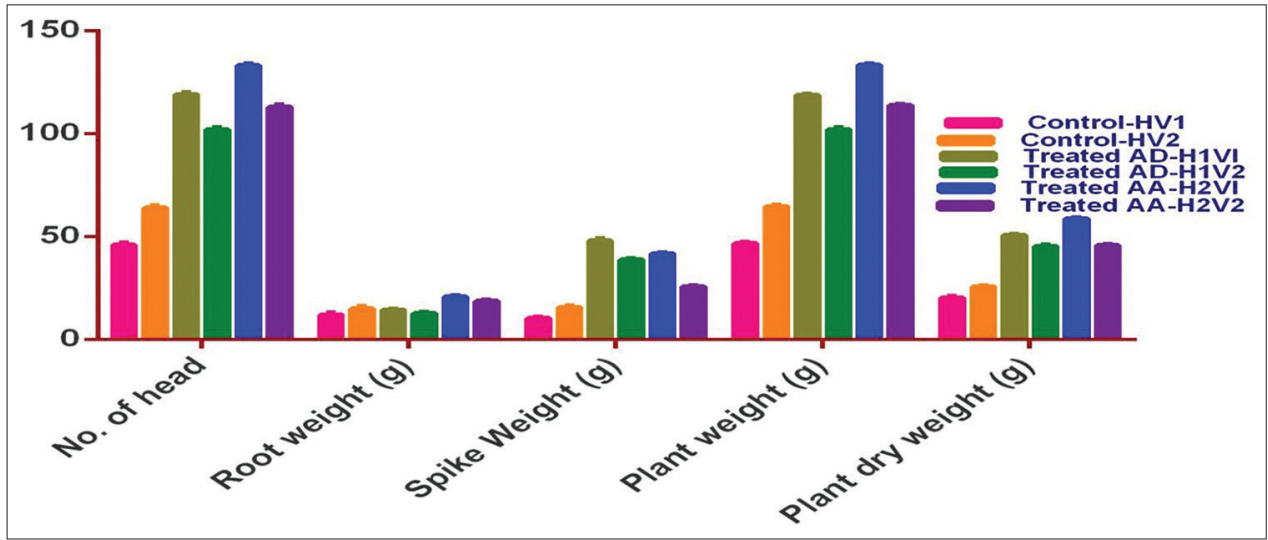

Fig 3. Analysis of agronomic parameters of wheat plant grown in irrigated wastewater samples.

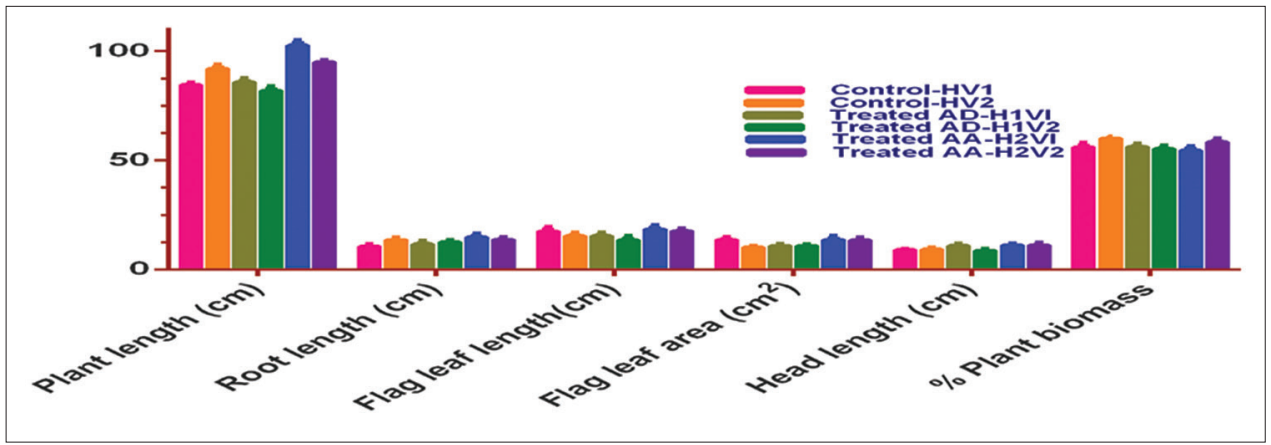

Fig 4. Analysis of growth parameters of wheat plant grown in irrigated wastewater Samples.

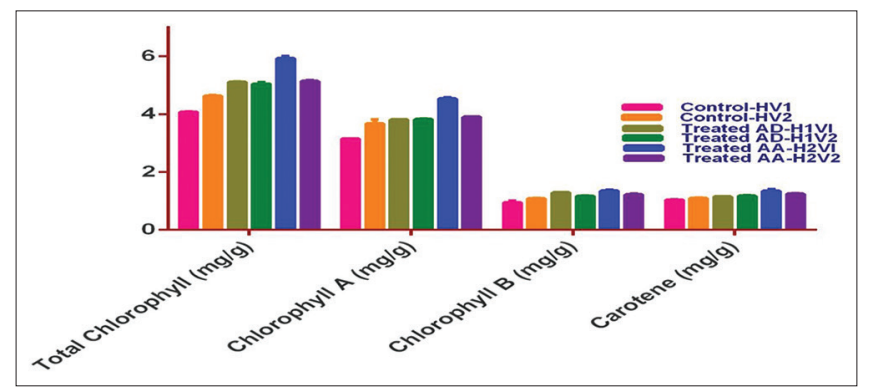

Fig 5. Analysis of chlorphyll and carotene content in wheat plant grown in irrigated wastewater samples. reproduction (Soetan et al., 2010). In the present study, advisable amounts of nitrogen $(\mathrm{N})$, phosphorous $(\mathrm{P})$ and potassium $(\mathrm{K})$ were observed in root, shoot and head parts of wheat plants grown in control and treated wastewater. On the other hand, they had lower content of macro elements in H2 (Table 3). Moreover, higher electrical conductivity of $\mathrm{H} 1$ hinders nutrient uptake by increasing osmotic pressure. The macro inorganic elements were in an optimum range according to Landis et al. (1990). Goddek and Korner (2019), the higher pH will increase the 
Hamedi, et al.

Table 2: N, P and $\mathrm{K}$ content in root, shoot and head part of wheat grown under irrigated wastewater samples

\begin{tabular}{|c|c|c|c|c|c|c|c|c|c|}
\hline \multirow[b]{2}{*}{ Parameter } & $\mathbf{N} \%$ & $\mathbf{P} \%$ & K \% & $\mathrm{N} \%$ & $\mathbf{P} \%$ & K \% & $\mathrm{N} \%$ & $\mathbf{P} \%$ & $\mathrm{~K} \%$ \\
\hline & \multicolumn{3}{|c|}{ Root } & \multicolumn{3}{|c|}{ Shoot } & \multicolumn{3}{|c|}{ Head } \\
\hline HV1 & $0.68 \pm 0.06$ & $0.07 \pm 0.01$ & $0.79 \pm 0.04$ & $1.21 \pm 0.02$ & $0.31 \pm 0.02$ & $1.54 \pm 0.02$ & $1.46 \pm 0.02$ & $0.46 \pm 0.03$ & $0.72 \pm 0.05$ \\
\hline H1V1 & $0.48 \pm 0.04$ & $0.07 \pm 0.01$ & $0.82 \pm 0.03$ & $0.88 \pm 0.04$ & $0.26 \pm 0.01$ & $1.55 \pm 0.16$ & $1.49 \pm 0.12$ & $0.43 \pm 0.06$ & $0.75 \pm 0.04$ \\
\hline H1V2 & $0.65 \pm 0.02$ & $0.10 \pm 0.02$ & $0.99 \pm 0.02$ & $1.04 \pm 0.05$ & $0.25 \pm 0.03$ & $1.47 \pm 0.07$ & $1.50 \pm 0.11$ & $0.43 \pm 0.01$ & $0.73 \pm 0.08$ \\
\hline HV2 & $0.75 \pm 0.04$ & $0.11 \pm 0.09$ & $0.93 \pm 0.01$ & $1.28 \pm 0.01$ & $0.37 \pm 0.02$ & $1.55 \pm 0.13$ & $1.48 \pm 0.13$ & $0.50 \pm 0.05$ & $0.76 \pm 0.06$ \\
\hline $\mathrm{H} 2 \mathrm{~V} 1$ & $0.70 \pm 0.06$ & $0.07 \pm 0.01$ & $1.00 \pm 0.03$ & $1.04 \pm 0.03$ & $0.29 \pm 0.01$ & $1.57 \pm 0.15$ & $1.59 \pm 0.12$ & $0.49 \pm 0.02$ & $0.82 \pm 0.09$ \\
\hline H2V2 & $0.72 \pm 0.62$ & $0.08 \pm 0.02$ & $1.03 \pm 0.02$ & $0.99 \pm 0.07$ & $0.35 \pm 0.02$ & $1.60 \pm 1.14$ & $1.46 \pm 0.13$ & $0.55 \pm 0.06$ & $0.87 \pm 0.03$ \\
\hline
\end{tabular}

Table 3: Microelemeteal trace elemental composisition (\%) in root, shoot and head part of wheat grown under irrigated wastewater samples

\begin{tabular}{|c|c|c|c|c|c|c|}
\hline Parameter & HV1 & H1V1 & H1V2 & HV2 & H2V1 & $\mathrm{H} 2 \mathrm{~V} 2$ \\
\hline \multicolumn{7}{|c|}{ Root } \\
\hline Manganese & 173.51 & 45.4 & 41.7 & 119.7 & 83.4 & 102.7 \\
\hline Iron & 104.23 & 72 & 11.045 & 113 & 93 & 62 \\
\hline Boron & 16.01 & 10.34 & 14.58 & 14.6 & 12.97 & 10.75 \\
\hline Zinc & 8.04 & 3.68 & 10.8 & 11.12 & 5.2 & 9.5 \\
\hline Sodium & 0.40 & 1.22 & 1.32 & 0.42 & 0.66 & 0.54 \\
\hline Magnesium & 0.10 & 0.17 & 0.20 & 0.11 & 0.12 & 0.10 \\
\hline Calcium & 0.47 & 0.25 & 0.35 & 0.53 & 0.41 & 0.34 \\
\hline Potassium & 0.79 & 0.82 & 0.99 & 0.93 & 1.00 & 1.03 \\
\hline \multicolumn{7}{|c|}{ Shoot } \\
\hline Manganese & 12.7 & 9.21 & 9.51 & 12.4 & 8.46 & 10.2 \\
\hline Iron & 122 & 146 & 139 & 120 & 139 & 130 \\
\hline Boron & 19.7 & 13.25 & 9.85 & 21.2 & 11.7 & 10.9 \\
\hline Zinc & 30 & 16.85 & 13.2 & 13.24 & 39.54 & 36.34 \\
\hline Sodium & 0.11 & 0.59 & 0.63 & 0.08 & 0.10 & 0.11 \\
\hline Magnesium & 0.17 & 0.22 & 0.23 & 0.17 & 0.19 & 0.18 \\
\hline Calcium & 0.32 & 0.28 & 0.25 & 0.29 & 0.27 & 0.28 \\
\hline Potassium & 1.54 & 1.55 & 1.47 & 1.55 & 1.57 & 1.60 \\
\hline \multicolumn{7}{|c|}{ Head } \\
\hline Manganese & 16.5 & 12.15 & 12.29 & 16.17 & 11.07 & 12.74 \\
\hline Iron & 106 & 147 & 156 & 109 & 179 & 166 \\
\hline Boron & 32.3 & 24.75 & 19.46 & 30.14 & 22.2 & 21.8 \\
\hline Zinc & 49.9 & 25.2 & 33.62 & 52.7 & 45.3 & 43.6 \\
\hline Sodium & 0.06 & 0.07 & 0.09 & 0.05 & 0.07 & 0.06 \\
\hline Magnesium & 0.26 & 0.24 & 0.25 & 0.26 & 0.28 & 0.27 \\
\hline Calcium & 0.33 & 0.26 & 0.24 & 0.33 & 0.28 & 0.30 \\
\hline Potassium & 0.72 & 0.76 & 0.73 & 0.76 & 0.82 & 0.87 \\
\hline
\end{tabular}

absorption of phosphorus, sulfate and nitrate by the root. Several researchers have documented higher NPK content in treated wastewater in comparison to well water. Irrigation with treated wastewater has been shown to increase soil $\mathrm{pH}$, electrical conductivity, OM, major elements, salts and heavy metals such as $\mathrm{Mn}, \mathrm{Zn}$ and Fe compared with well water (Bedbabis et al., 2015).

\section{Analysis of micro, secure and trace elements}

The quantities of micro, secure and trace elements were determined before and after the treatments. The results are summarized in Table 4. Mineral content in shoots was significantly different $(\mathrm{p}<0.05)$ among the three water treatments. However, no differences were found between both cultures, except for $\mathrm{N}$ and $\mathrm{Mg}$. Production was higher in $\mathrm{H} 2$ treated plants than in $\mathrm{H} 1$ treated plants. Similarly, higher $\mathrm{N}$ content was detected in the $\mathrm{H} 2$ compared to $\mathrm{H} 1$. This was also the case with P, Ca and Mg content. Significant interactions were found between water treatment and N, P, $\mathrm{K}$ and $\mathrm{Mg}$ content in shoot and $\mathrm{Mg}$ in root. This confirms different patterns of response in both the wheat varieties grown in different waters hydroponically.

\section{Heavy metal accumulation in wheat plant}

Many researchers have addressed the potential health risks of accumulation of heavy metals in plants. Most of the toxic heavy metals are carcinogenic in nature. This heavy metal risk can be determined employing different methods such as transfer factor (TF), daily intake of metals (DIM), health risk index (HRI) and health quotient (HQ) (Khan et al., 2008).

In the present study, heavy metal accumulation before and after the treatments were examined (Table 5). The results indicated that all metals in the food crops exceeded acceptable limits. In H1V1 treatment, the wheat plants showed Al concentration of $5.35 \mathrm{mg} / \mathrm{g}$, while concentration of $\mathrm{Sr}$ was $4 \mathrm{mg} / \mathrm{g}$. The concentration of $\mathrm{Cr}$ was observed around $0.87 \mathrm{mg} / \mathrm{g}$, while the concentration of $\mathrm{Ni}$ was found be $0.1 \mathrm{mg} / \mathrm{g}$. However in H2V2 treatment, the plants have accumulated around $4.6 \mathrm{mg} / \mathrm{g}$ of $\mathrm{Al}, 4.2 \mathrm{mg} / \mathrm{g}$ of $\mathrm{Sr}, 4.08 \mathrm{mg} / \mathrm{g}$ of $\mathrm{Ni}, 2.2 \mathrm{mg} / \mathrm{g}$ of $\mathrm{Ba}, 1.08 \mathrm{mg} / \mathrm{g}$ of $\mathrm{Cr}$ and $1.3 \mathrm{mg} / \mathrm{g}$ of $\mathrm{Pb}$. The overall trend of heavy metal concentrations in plants was in the order $\mathrm{Al}>\mathrm{Sr}>\mathrm{Pb}>\mathrm{Ba}<\mathrm{Cr}>\mathrm{Ni}$. This variation is due to the different physicochemical nature of the two different wastewaters and absorption capacity of plant varieties.

\section{Effect of irrigated waste water in yield parameters of wheat}

The cumulative yields of wheat plant have been measured with respect to the number of spikes, spike length, number of grains/head, grain yield and 1000 kernel weight (Fig. 6). The harvest data suggest that the H2VI plants showed superior yield among the tested plants. They showed plant length of $9.12 \mathrm{~cm}$, spike length of $8.30 \mathrm{~cm}$, grain per spike of $43.71 \mathrm{~cm}$ and thousand kernel weight of $42.19 \mathrm{~g}$. The H1V1 plants showed plant length of $10.15 \mathrm{~cm}$, spike length of $8.24 \mathrm{~cm}$, grain per spike of $41.12 \mathrm{~cm}$ and thousand 
Hamedi, et al.

Table 4: Microelements, secure elements and trace element content in before and after the treatment of irrigated wastewater sample

\begin{tabular}{|c|c|c|c|c|c|c|c|c|}
\hline \multirow[t]{2}{*}{ Parameter } & \multicolumn{2}{|c|}{ Before } & \multicolumn{6}{|c|}{ After the Treatment } \\
\hline & HVI & HV2 & HV1 & H1V1 & H1V2 & HV2 & H2V1 & H2VT2 \\
\hline Nitrogen & 1.53 & 1.87 & 2.58 & 2.46 & 2.82 & 2.62 & 2.56 & 2.72 \\
\hline Phosphorus & 0.33 & 0.38 & 0.36 & 0.34 & 0.39 & 0.37 & 0.41 & 0.43 \\
\hline Potassium & 0.24 & 0.29 & 0.23 & 0.19 & 0.24 & 0.22 & 0.28 & 0.30 \\
\hline Calcium & 0.07 & 0.04 & 0.05 & 0.05 & 0.05 & 0.08 & 0.10 & 0.30 \\
\hline Magnesium & 0.16 & 0.15 & 0.13 & 0.013 & 0.13 & 0.14 & 0.15 & 0.19 \\
\hline Sulphur & 1.23 & 0.14 & 0.16 & 0.09 & 0.09 & 0.15 & 0.13 & 0.14 \\
\hline Sodium & 0.00 & 0.01 & 0.02 & 0.02 & 0.02 & 0.01 & 0.10 & 0.13 \\
\hline Iron & 58.80 & 44.56 & 27.9 & 27.1 & 27.1 & 45.6 & 29.9 & 15.5 \\
\hline Copper & 11.5 & 5.00 & 5.93 & 6.03 & 6.03 & 7.33 & 6.50 & 6.75 \\
\hline Manganese & 5.54 & 6.59 & 17.9 & 13.8 & 13.8 & 25.7 & 26.1 & 39.1 \\
\hline Zinc & 47.22 & 37.92 & 22.6 & 13.1 & 13.0 & 22.3 & 15.6 & 15.0 \\
\hline
\end{tabular}

Table 5: Heavy metal accumulation in root, shoot and head part of wheat grown under irrigated wastewater samples

\begin{tabular}{|c|c|c|c|c|c|c|}
\hline Parameter & HV1 & H1V1 & H1V2 & HV2 & H2V1 & H2V2 \\
\hline \multicolumn{7}{|c|}{ Root } \\
\hline Copper & 177.21 & 136.75 & 178.41 & 224.63 & 167.22 & 137.56 \\
\hline Nickel & 0.0 & 0.00 & 0.1 & 0.0 & 0.0 & 0.0 \\
\hline Lead & 4.22 & 4.29 & 4.63 & 4.59 & 2.10 & 4.46 \\
\hline Strontium & 3.3 & 1.7 & 0.0 & 3.6 & 3.4 & 6.0 \\
\hline Aluminium & 19 & 30 & 36 & 21 & 27 & 22 \\
\hline Barium & 12.25 & 3.20 & 4.67 & 10.08 & 6.58 & 6.57 \\
\hline Cadmium & 0.38 & 0.24 & 0.42 & 0.35 & 0.07 & 0.51 \\
\hline Cobalt & 0.00 & 0.08 & 0.34 & 0.10 & 0.08 & 0.00 \\
\hline Chromium & 7.76 & 8.59 & 7.85 & 8.81 & 5.83 & 6.13 \\
\hline Arsenic & 0.0 & 0.00 & 0.0 & 0.0 & 0.0 & 0.0 \\
\hline Selenium & 0.0 & 0.00 & 0.0 & 0.0 & 0.0 & 0.0 \\
\hline \multicolumn{7}{|c|}{ Shoot } \\
\hline Copper & 190.92 & 219.63 & 175.26 & 195.12 & 206.36 & 249.87 \\
\hline Nickel & 0.00 & 0.00 & 0.00 & 0.00 & 0.00 & 0.00 \\
\hline Lead & 3.43 & 2.83 & 2.30 & 3.25 & 2.21 & 3.27 \\
\hline Strontium & 3.5 & 0.00 & 0.4 & 3.3 & 0.7 & 0.6 \\
\hline Aluminium & 16 & 3.5 & 35 & 14 & 26 & 25 \\
\hline Barium & 16.11 & 4.38 & 4.30 & 13.06 & 9.46 & 7.29 \\
\hline Cadmium & 0.18 & 0.40 & 0.35 & 0.37 & 0.10 & 0.40 \\
\hline Cobalt & 0.00 & 0.29 & 0.00 & 0.00 & 0.04 & 0.05 \\
\hline Chromium & 5.55 & 5.63 & 5.13 & 5.48 & 5.55 & 5.75 \\
\hline Arsenic & 0.00 & 0.00 & 0.00 & 0.00 & 0.00 & 0.00 \\
\hline Selenium & 0.00 & 0.00 & 0.00 & 0.00 & 0.00 & 0.00 \\
\hline \multicolumn{7}{|c|}{ Head } \\
\hline Copper & 193.55 & 190.56 & 218.74 & 214.62 & 260.25 & 243.89 \\
\hline Nickel & 0.00 & 0.00 & 0.00 & 0.00 & 0.00 & 0.00 \\
\hline Lead & 1.04 & 3.81 & 2.82 & 1.76 & 3.22 & 4.49 \\
\hline Strontium & 1.70 & 4.2 & 1.81 & 4.00 & 2.9 & 0.5 \\
\hline Aluminium & 14 & 24 & 23 & 13 & 25 & 26 \\
\hline Barium & 13.49 & 3.73 & 3.27 & 10.40 & 7.46 & 5.20 \\
\hline Cadmium & 0.36 & 0.01 & 0.34 & 0.19 & 0.20 & 0.12 \\
\hline Cobalt & 0.20 & 0.42 & 0.00 & 0.20 & 0.18 & 0.03 \\
\hline Chromium & 5.94 & 6.28 & 6.46 & 6.08 & 7.75 & 7.15 \\
\hline Arsenic & 0.00 & 0.00 & 0.00 & 0.00 & 0.00 & 0.00 \\
\hline Selenium & 0.00 & 0.00 & 0.00 & 0.00 & 0.00 & 0.00 \\
\hline
\end{tabular}

kernel weight of 34.64 g. Several pilot and experimental investigations including pot and land fill studies for

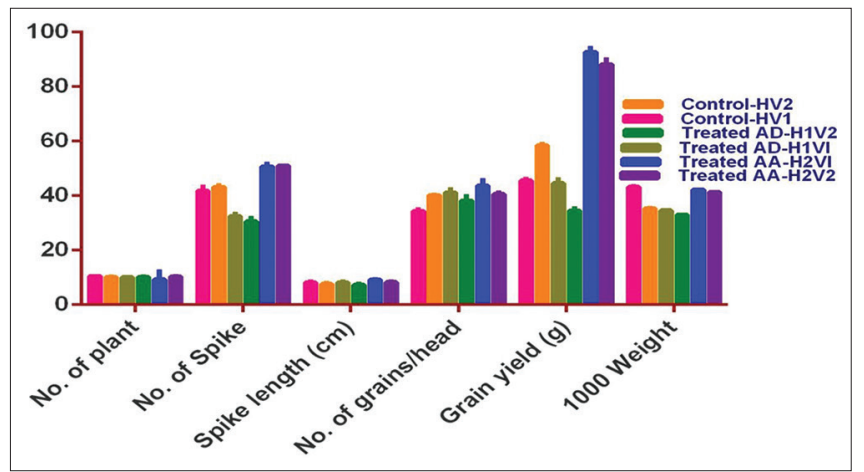

Fig 6. The growth yield variables of wheat plant grown in irrigated wastewater samples.

growth and yield parameters of wheat plant irrigated with wastewater have been carried out (Oweis et al., 1988; Shirazi et al., 2014). According to Bhattarai et al. (2017) the grain yield for V2 is $2206.66 \mathrm{~kg} / \mathrm{ha}$, who harvested the mature grains after 135-184 days. Similar findings were observed in this study (Mon et al., 2016, Wang et al., 2016).

\section{Effect of irrigated waste water in fiber and crude protein content}

Analysis of fiber and protein Content in edible plant is an important key factor for nutritional value. In the present investigation, Fiber and crude protein content were analysed in two different site of treatment plant, and this findings were shown in Table 6. Higher contents of neutral detergent fiber (NDF), acid detergent fiber (ADF) and crude protein content were observed in $\mathrm{H} 2 \mathrm{~V} 2$ treated samples. The fiber and protein contents determined in the present work are also comparable with some other forage and nutritionaslyy important plants.

\section{Heavy metal accumulation before and after the treatment}

Table 7 shows the heavy metal accumulation of nickel, lead, strontium, aluminium, barium, cobalt, chromium, arsenic and selenium in the plant species before and after treatment. 
Hamedi, et al.

Table 6: Fiber and crude protein content in root and shoot part of wheat grown under irrigated wastewater samples

\begin{tabular}{|c|c|c|c|c|c|c|}
\hline \multirow[t]{2}{*}{$\begin{array}{l}\text { Part of } \\
\text { the plant }\end{array}$} & $\begin{array}{c}\text { Neutral Detergent } \\
\text { Fiber (NDF) \% }\end{array}$ & $\begin{array}{l}\text { Acid Detergent } \\
\text { Fiber (ADF) \% }\end{array}$ & $\begin{array}{c}\text { Crude } \\
\text { Protein } \%\end{array}$ & $\begin{array}{c}\text { Neutral Detergent } \\
\text { Fiber (NDF) \% }\end{array}$ & $\begin{array}{c}\text { Acid Detergent } \\
\text { Fiber (ADF) \% }\end{array}$ & $\begin{array}{c}\text { Crude } \\
\text { Protein \% }\end{array}$ \\
\hline & \multicolumn{3}{|c|}{ Root } & \multicolumn{3}{|c|}{ Shoot } \\
\hline HV1 & $59.49 \pm 2.15$ & $34.72 \pm 2.14$ & $7.54 \pm 0.95$ & $56.20 \pm 4.85$ & $27.46 \pm 2.07$ & $9.15 \pm 0.93$ \\
\hline HV2 & $64.52 \pm 2.56$ & $36.45 \pm 2.98$ & $8.01 \pm 0.76$ & $58.36 \pm 5.01$ & $30.22 \pm 3.01$ & $9.33 \pm 0.89$ \\
\hline H1V1 & $60.10 \pm 4.48$ & $35.64 \pm 3.47$ & $5.50 \pm 4.45$ & $47.54 \pm 4.26$ & $22.89 \pm 2.64$ & $9.32 \pm 0.71$ \\
\hline H1V2 & $60.97 \pm 5.45$ & $34.15 \pm 3.87$ & $6.48 \pm 0.55$ & $53.66 \pm 5 W .03$ & $23.38 \pm 2.09$ & $9.37 \pm 0.81$ \\
\hline H2V1 & $63.39 \pm 5.12$ & $27.81 \pm 2.09$ & $6.47 \pm 0.63$ & $51.51 \pm 4.78$ & $24.61 \pm 2.16$ & $9.93 \pm 0.88$ \\
\hline H2V2 & $62.72 \pm 6.02$ & $36.09 \pm 3.44$ & $6.18 \pm 0.53$ & $57.84 \pm 3.89$ & $27.12 \pm 2.89$ & $9.11 \pm 0.86$ \\
\hline
\end{tabular}

Table 7: Heavy metal accumulation in before and after the treatment of Irrigation waste water treatment

\begin{tabular}{|c|c|c|c|c|c|c|c|c|}
\hline \multirow[t]{2}{*}{ Parameter } & \multicolumn{2}{|c|}{ Before } & \multicolumn{6}{|c|}{ After the treatment } \\
\hline & VI & V2 & HV1 & H1V1 & H1V2 & HV2 & H2V1 & H2V2 \\
\hline Nickel & 2.18 & 2.37 & 0 & 0.1 & 0 & 1.01 & 0 & 4.08 \\
\hline Lead & 1.77 & 2.19 & 4.01 & 0.0 & 4.06 & 0.00 & 2.09 & 1.03 \\
\hline Strontium & 13.3 & 12 & 3.2 & 4 & 5.4 & 4.0 & 5.0 & 18.2 \\
\hline Aluminium & 26.11 & 22.01 & 7.5 & 5.35 & 7.07 & 5.35 & 6.35 & 16.6 \\
\hline Barium & 0.71 & .64 & 1.1 & 0.4 & 0.4 & 0.4 & 0.3 & 2.2 \\
\hline Cobalt & 0.00 & .17 & 0.0 & 0.0 & 0.00 & 0.00 & 0.87 & 0.15 \\
\hline Chromium & 3.01 & 2.32 & 1.26 & 0.87 & 1.85 & 1.85 & 1.34 & 2.82 \\
\hline Arsenic & 5.82 & 0.00 & 0.0 & 0.0 & 0.0 & 0.0 & 0.0 & 0.0 \\
\hline Selenium & 1.48 & 0.00 & 0.0 & 0.0 & 0.0 & 0.0 & 0.0 & 0.0 \\
\hline
\end{tabular}

Selenium and arsenic were not detected in any plant species grown in treated wastewaters from Abu Dhabi (H1) or Al Ain (H2). Uptake of $\mathrm{Cr}, \mathrm{Al}, \mathrm{Sr}$ and $\mathrm{Pb}$ by the plants indicates the accumulation process in the plant body. The study clearly shows plant species grown $\mathrm{H} 1$ have the higher heavy metal accumulation, which may be due to scarcity of water.

\section{CONCLUSIONS}

Wheat plants irrigated with domestic waste water had the highest agronomy values compared to the other irrigated waste water and groundwater. The overall findings of the study suggested that the growth and yield parameters were improved as a result of irrigation with treated wastewater by hydroponic method. The favorable physicochemical nature, adequate amount of trace metals and other physiological factors influenced the growth and yield of wheat plant. Among the two different sources of treated wastewater, the wheat plants grown in treated wastewater sourced from Al Ain produced a higher yield.

\section{ACKNOWLEDGMENTS}

We wish to express our gratitude to the United Arab Emirates University for providing the facilities for the study.

\section{CONFLICTS OF INTEREST}

The authors declare no conflict of interest.

\section{Author contributions}

FHAH conducted the research work, interpreted the data, and prepared the manuscript; MAS provided the guidance for experimental design and help interpreted the data; MAS and KK critically reviewed the manuscript.

\section{REFERENCES}

Abdelkhalek, E. A., B. Mohamed, A. M. Mohammed and A. Lotfi. 2016. Growth performance and biochemical composition of nineteen microalgae collected from different Moroccan reservoirs. Mediterr. Mar. Sci. 17: 323-332.

Aleisa, E. and W. Al-Zubari. 2017. Wastewater reuse in the countries of the Gulf Cooperation Council (GCC): The lost opportunity. Environ. Monit. Assess. 189: 553

Al-Karaki, G. N. 2011. Utilization of treated sewage wastewater for green forage production in a hydroponic system. Emir. J. Food Agric. 23: 80-94.

Al-Karaki, G. N. and M. Al-Hashimi. 2011. Green fodder production and water use efficiency of some forage crops under hydroponic conditions. Int. Sch. Res. Notices. 2012: 924672.

Al-Muaini, A., O. M. Sallam, S. Green, L. Kennedy, P. Kemp and B. Clothier. 2019. The blue and grey water footprints of date production in the saline and hyper-arid deserts of United Arab Emirates. Irrig. Sci. 37: 657-667.

Aulakh, M. S., J. S. Manchanda, A. K. Garg, S. Kumar, G. Dercon and M. L. Nguyen. 2012. Crop production and nutrient use efficiency of conservation agriculture for soybean-wheat rotation in the Indo-Gangetic Plains of Northwestern India. Soil. Tillage. Res. 120: 50-60.

Bedbabis, S., D. Trigui, C. B. Ahmed, M. L. Clodoveo, S. Camposeo, G. A. Vivaldi and B. B. Rouina. 2015. Long-terms effects of irrigation with treated municipal wastewater on soil, yield and olive oil quality. Agric. Water Manag. 160: 14-21.

Bhattarai, N., P. Wagle, P. H. Gowda and V. G. Kakani. 2017. Utility of remote sensing-based surface energy balance models to track water stress in rain-fed switch grass under dry and wet conditions. J. Photogram. Remote Sens. 133: 128-141.

Bradley, P. and C. Marulanda. 2000. Simplified hydroponics to reduce global hunger. Acta Hortic. 554: 289-296.

Bressy, F. C., G. B. Brito, I. S. Barbosa, L. S. Teixeira and M. G. Korn. 2013. Determination of trace element concentrations in tomato samples at different stages of maturation by ICP OES and ICPMS following microwave-assisted digestion. Microchem. J. 109: 145-149.

Faithfull, N.T. 2002. Methods in Agricultural Chemical Analysis: A Practical Handbook. Centre for Agriculture and Bioscience International, Wallingford, United Kingdom. 
Goddek, S. and O. Körner. 2019. A fully integrated simulation model of multi-loop aquaponics: A case study for system sizing in different environments. Agric. Syst. 171: 143-154.

Grusak, M. A., M. R. Broadley, P. J. White. 2001. Plant macro and micronutrient minerals. In: eLS. Vol. 30. John Wiley and Sons, Ltd., Hoboken, New Jersey, pp. 1-6.

Hoagland, D. R. and D. I. Arnon. 1950. The Water-culture Method for Growing Plants without Soil. 2nd ed., Vol. 347. California Agricultural Experiment Station, California.

Kabra, K., R. Chaudhary, R. L. Sawhney. 2004. Treatment of hazardous organic and inorganic compounds through aqueous-phase photocatalysis: A review. Ind. Eng. Chem. Res. 43: 7683-7696.

Kamel, A. Z. and A. Nada. 2008. Performance of wastewater treatment plants in Jordan and suitability for reuse. Afr. J. Biotechnol. 7: 2621-2629.

Khan, M. U., R. N. Malik and S. Muhammad. 2013. Human health risk from heavy metal via food crops consumption with wastewater irrigation practices in Pakistan. Chemosphere. 93: 2230-2238.

Koop, S. H. and C. J. van Leeuwen. 2017. The challenges of water, waste and climate change in cities. Environ. Dev. Sustain. 19: 385-418.

Landis, T. D. and R. G. Nisley. 1990. The Container Tree Nursery Manual: Seedling Nutrition and Irrigation. Department of Agriculture Forest Service. USDA Forest Service, Washington, DC.

Magomya, A. M., D. Kubmarawa, J. A. Ndahi and G. G.Yebpella. 2014. Determination of plant proteins via the kjeldahl method and amino acid analysis: A comparative study. Int. J. Sci. Technol. Res. 3: 68-72.

Mon, J., K. F. Bronson, D. J. Hunsaker, K. R. Thorp, J. W. White and A. N. French. 2016. Interactive effects of nitrogen fertilization and irrigation on grain yield, canopy temperature, and nitrogen use efficiency in overhead sprinkler-irrigated durum wheat. Field Crops Res. 191: 54-65.

Murad, A. A., H. Al Nuaimi and M. Al Hammadi. 2007. Comprehensive assessment of water resources in the United Arab Emirates (UAE). Water Resour. Manage. 21: 1449-1463.

Nouri, H., S. C. Borujeni, R. Nirola, A. Hassanli, S. Beecham, S. Alaghmand, C. Saint and D. Mulcahy. 2017. Application of green remediation on soil salinity treatment: A review on halophytoremediation. Proc. Saf. Environ. Prot. 107: 94-107.

Oweis, T., M. Pala and J. Ryan. 1998. Stabilizing rainfed wheat yields with supplemental irrigation and nitrogen in a Mediterranean climate. Agron. J. 90: 672-681.

Pais, I., J. B. Jr. Jones. 1997. The Handbook of Trace Elements. CRC
Press, Boca Raton, Florida.

Porra, R. J., W. A. Thompson and P. E. Kriedemann. 1989. Determination of accurate extinction coefficients and simultaneous equations for assaying chlorophylls a and b extracted with four different solvents: Verification of the concentration of chlorophyll standards by atomic absorption spectroscopy. Biochim. Biophys. Acta Bioenerg. 975: 384-394.

Rababah, A. and A. Al-Shuha. 2009. Hydroponics reducing effluent's heavy metals discharge. Water Sci. Technol. 59: 175-183.

Rahneshan, Z., F. Nasibi and A. A. Moghadam. 2018. Effects of salinity stress on some growth, physiological, biochemical parameters and nutrients in two pistachio (Pistacia vera L.) rootstocks. J. Plant Interact. 13: 73-82.

Ravichandran, M., M. Baskaran, P. H. Santschi and T. S. Bianchi. 1995. History of trace metal pollution in Sabine-Neches estuary, Beaumont, Texas. Environ. Sci. Technol. 29: 1495-1503.

Sharifi, P. and N. Mohammadkhani. 2016. Effects of drought stress on photosynthesis factors in wheat genotypes during anthesis. Cereal Res. Commun. 44: 229-239.

Shirazi, S. M., Z. Yusop, N. H. Zardari and Z. Ismail. 2014. Effect of irrigation regimes and nitrogen levels on the growth and yield of wheat. Adv. Agric. 2014: 250874.

Soetan, K. O., C. O. Olaiya and O. E. Oyewole. 2010. The importance of mineral elements for humans, domestic animals and plants a review. Afr. J. Food Sci. 4: 200-222.

Sudhir, P. and S. D. Murthy. 2004. Effects of salt stress on basic processes of photosynthesis. Photosynthetica. 42: 481-486.

Torrion, J. A. and R. N. Stougaard. 2017. Impacts and limits of irrigation water management on wheat yield and quality. Crop Sci. 57: 3239-3251.

Vaillant, N., F. Monnet, H. Sallanon, A. Coudret and A. Hitmi. 2004. Use of commercial plant species in a hydroponic system to treat domestic wastewaters. J. Environ. Qual. 33: 695-702.

Wang, B., Y. Zhang, B. Hao, X. Xu, Z. Zhao, Z. Wang and Q. Xue, Q. 2016. Grain yield and water use efficiency in extremely-late sown winter wheat cultivars under two irrigation regimes in the North China Plain. PLoS One. 1: e0153695.

Yadanaparthi, S. K., D. Graybill and R. von Wandruszka. 2009. Adsorbents for the removal of arsenic, cadmium, and lead from contaminated waters. J. Hazard. Mater. 171: 1-5.

Zhang, X., L. Liu and G.M. Henebry. 2019. Impacts of land cover and land use change on long-term trend of land surface phenology: A case study in agricultural ecosystems. Environ. Res. Let. 14: 044020 . 